\title{
Statement by HE Ghislain D'hoop, Ambassador of the Kingdom of Belgium
}

\author{
Ghislain D'hoop
}

In 1929, survivors of the French 418th infantry regiment erected a monument in Zuidschote, just to the North of Ypres. It was dedicated to the memory of their comrades killed or maimed by the chlorine gas attack at $5 \mathrm{pm}$ on the 22nd of April, exactly one hundred years ago. The main victims of the attacks on that day and two days later were French, Moroccan, Algerian and other colonial forces, as well as 2,000 Canadian soldiers and more than 1,000 men of the Belgian Grenadier Guards and Carabiniers. Together with the British and Commonwealth forces, all were engaged in what later became known as the Second Battle of Ypres.

The 1929 French monument no longer exists. It was destroyed in 1942, during the Second World War. In its place, on the same spot, now stands a cross of reconciliation erected by the French and Belgian authorities. A moving Canadian memorial, the Brooding Soldier, stands somewhat further along the former frontline. And in Ottawa, paintings by William Patrick Roberts and Richard Jack also evoke the first chemical attack in the Ypres Salient. The Council Room at OPCW's headquarters in The Hague is called the Ypres Room. And famously, of course, the gas attacks are given strong poetical meaning in Wilfred Owen's poem, Dulce Et Decorum Est.

Commemoration, reconciliation, peace, international cooperation: they are key principles of humanity, embedded in our minds and in our hearts, and they must always be rekindled and never forgotten. Monuments in stone or bronze help us to achieve this difficult but necessary undertaking. So do paintings, poems and music since they touch our soul, help us to comprehend the unfathomable and make us better human beings. There is a special role to play for diplomats and scientists, in making sure that the world fully understands the horrors of chemical warfare and unites in condemning its manufacturing, stockpiling and use.

\footnotetext{
G. D'hoop ( $\square)$

Belgian Embassy, Berlin, Germany

e-mail: ghislain.dhoop@diplobel.fed.de

(C) The Author(s) 2017

B. Friedrich et al. (eds.), One Hundred Years of Chemical Warfare: Research,

Deployment, Consequences, DOI 10.1007/978-3-319-51664-6_21
} 
I therefore congratulate you on this initiative to take stock of historical and scientific research on the use of chemical weapons. Today, it is fitting that we commemorate all the men and women, soldiers and civilians alike, who fell victim to the atrocious, horribly painful and debilitating effects of chlorine gas, of phosgene and of mustard gas, all used in the trenches of Flanders.

If the attack one hundred years ago teaches us anything, it is not only the particularly horrifying and perverse impact of chemical weapons upon the human body but also the extreme fear and psychological damage they cause. Indeed, the mere possibility of their use instils primeval fear and feelings of horror into any decent human being. Because of these effects, chemical weapons are truly a deterrent and can easily be construed as an instrument of mass annihilation.

A hundred years later, much has been achieved in our global reaction to chemical weapons. We abhor those who use them or threaten to do so, we are working together to destroy the remaining stockpiles, and we set up an international organisation, the OPCW, which won the Nobel Peace Prize for its unrelenting efforts toward a universal ban on chemical weapons.

But as the horrific events in Syria show, our vigilance must never abate. Sarin gas was used in a Damascus suburb in August 2013, and chlorine, the same chemical released on the Ypres front one hundred years ago, was used against innocent civilians.

Belgium knows what it means to remain vigilant. Especially the Flemish farmers ploughing their lands on what a hundred years ago was an international battlefield know the importance of careful handling of unexploded ammunition. Every spring, the land yields a harvest of warfare when around 200 tonnes of such explosive ordnance are found. Some 5\% of the ammunition found is of a chemical nature. These shells have to be disposed of through specialized techniques. The Explosive Ordnance Disposal Company of the Belgian army works all year round to eliminate these dangerous relics of World War I.

Because Belgium has suffered so severely under the impact of chemical attacks, we - its government, researchers, NGOs, and industry - are forerunners in international efforts to guarantee that the ban on the production, storage, and use of chemical weapons is effectively implemented worldwide.

Chemical weapons continue to be produced and even deployed. For this reason, it is crucial that their devastating impact continues to be widely recognized and understood. The current volume contributes magnificently to this noble undertaking. I am optimistic that the strong message conveyed by this joint scientific endeavor, a message of understanding through research and the power of international cooperation, will be heard and that in the coming years will also be acted upon. 
Open Access This chapter is licensed under the terms of the Creative Commons Attribution-NonCommercial 2.5 International License (http://creativecommons.org/licenses/by-nc/ $2.5 /$ ), which permits any noncommercial use, sharing, adaptation, distribution and reproduction in any medium or format, as long as you give appropriate credit to the original author(s) and the source, provide a link to the Creative Commons license and indicate if changes were made.

The images or other third party material in this chapter are included in the chapter's Creative Commons license, unless indicated otherwise in a credit line to the material. If material is not included in the chapter's Creative Commons license and your intended use is not permitted by statutory regulation or exceeds the permitted use, you will need to obtain permission directly from the copyright holder.

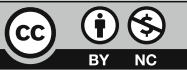

